\title{
The influence of moisture on the residual effects of natural zinc chelates applied to two different soils
}

\author{
P. Almendros*, D. Gonzalez and J.M. Alvarez \\ Departamento de Química y Análisis Agrícola, Escuela Técnica Superior de Ingenieros Agrónomos (ETSIA), Universidad \\ Politécnica de Madrid (UPM), El Greco, Ciudad Universitaria s/n 28040 Madrid, Spain. "Corresponding author: p.almendros@ \\ upm.es
}

\begin{abstract}
The aim of this study was to compare the behavior of residual $\mathrm{Zn}$ from three natural chelates $\mathrm{Zn}$-aminolignosulfonate [Zn-AML],Zn-polyhydroxyphenylcarboxylate [Zn-PHP] and Zn-ethylenediamine disuccinate [Zn-EDDS]) applied at different rates $(0,5$ and $10 \mathrm{mg} \mathrm{Zn/kg}$ soil) to a flax crop grown during the previous year. This incubation experiment was carried out over 75 days under two different moisture conditions (60\% field capacity and waterlogged) in two different soils (acidic [Soil ${ }_{\text {acid }}$ ] and calcareous [Soil ${ }_{\text {calc }}$ ). The potential available $\mathrm{Zn}$ concentration and shortterm available $\mathrm{Zn}$ were estimated under both moisture conditions using the diethylenetriaminepentaacetic acid triethanolamine (DTPA-TEA) and low-molecular-weight organic acids (LMWOAs) methods, respectively. Watersoluble $\mathrm{Zn}$ was estimated in both soils under $60 \%$ field capacity conditions. Immediately available $\mathrm{Zn}$ (the $\mathrm{Zn}$ concentration in the soil solution) was estimated under waterlogged conditions. The $\mathrm{pH}$ and Eh were also determined in both soils. Incubation of both soils under both moisture conditions led to decreases in the potential available $\mathrm{Zn}$ and short-term available $\mathrm{Zn}$ concentrations. Water-soluble $\mathrm{Zn}$ concentrations in soils under $60 \%$ field conditions, immediately available $\mathrm{Zn}$ in soils and the Eh parameter under waterlogged conditions also decreased with time. The residual effect of Zn-AML applied at a rate of $10 \mathrm{mg} \mathrm{Zn/kg} \mathrm{in} \mathrm{Soil} \mathrm{acid} \mathrm{produced} \mathrm{the} \mathrm{highest} \mathrm{available} \mathrm{and} \mathrm{short-term}$ $\mathrm{Zn}$ concentrations, and the residual effect of Zn-EDDS produced the highest short-term Zn concentration in Soil ${ }_{\text {calc }^{*}}$
\end{abstract}

Keywords: Zn chelates, residual effect, $\mathrm{Zn}$ availability, short-term available $\mathrm{Zn}$, immediately available Zn, watersoluble $\mathrm{Zn}$

\section{Introduction}

When $\mathrm{Zn}$ is applied to the soil, water-soluble $\mathrm{Zn}$ is distributed between the solid phases and the soil solution. As this metal ages in the soil, changes in $\mathrm{Zn}$ availability, reductions in the activity and extractability of $\mathrm{Zn}$ forms and alterations in the more stable forms of $\mathrm{Zn}$ over intermediate and longer periods can be observed (Barrow, 1986; Shuman,
1991; Ma and Uren, 2006). This process is influenced by various parameters, such as moisture conditions, soil characteristics and time.

The soil moisture content has an effect on nutrient bioavailability, as it influences the mineralization of nutrients from soil organic matter. 
In soils, redox conditions affect aging processes and the availability of metals. Redox conditions generally exert control over $\mathrm{pH}$ and influence the availability of metal ions as well as the chemical forms of ions and molecules dissolved in the soil solution (McBride, 1994; Violante et al., 2010). Different soil pH levels also influence $\mathrm{Zn}$ availability over time. In general, the concentration of water-soluble $\mathrm{Zn}$ decreases as the $\mathrm{pH}$ increases. According to Liang et al. (1990), under acidic soil conditions, the concentration of exchangeable $\mathrm{Zn}$ is high. Payne et al. (1988) reported that when $\mathrm{ZnSO}_{4}$ was applied to high $\mathrm{pH}$ soil, most of the $\mathrm{Zn}$ was not available to plants.

According to Martinez and McBride (2000), increasing the aging time causes a decrease in $\mathrm{Zn}$ solubility. Various studies have reported differences in available $\mathrm{Zn}$ concentrations over 8-day periods of $\mathrm{ZnSO}_{4}$ fertilizer application (Armour et al., 1989), decreases in soluble $\mathrm{Zn}$ concentrations over 30-dayperiods of $\mathrm{Zn}\left(\mathrm{NO}_{3}\right)_{2}$ application (Barrow, 1986) and decreases in the amount of $\mathrm{Zn}$ in soil solutions over 3 days of carrier-free ${ }^{65} \mathrm{Zn}$ application (Tiller et al., 1972).

Different $\mathrm{Zn}$ fertilizers applied to soils demonstrate different levels of reactivity, solubility and availability. In recent years, the use of $\mathrm{Zn}$ chelates has been proposed as a means of providing this micronutrient to obtain high concentrations of water-soluble $\mathrm{Zn}$ and available $\mathrm{Zn}$ in soils, especially in calcareous soils (Obrador et al., 2002). The effectiveness of these sources depends on the stability of the chelate in question. Several studies have demonstrated the evolution of available $\mathrm{Zn}$ and $\mathrm{Zn}$ in soil solutions (immediately available $\mathrm{Zn}$ ) in soils planted with maize crops (Lopez-Valdivia et al., 2002, Alvarez and Rico, 2003). However, studies examining the residual effect of applying $\mathrm{Zn}$ in the form of natural chelates, the influence of moisture conditions on the availability of $\mathrm{Zn}$ and the short-term evolution of residual $\mathrm{Zn}$ are still very limited (Almendros et al., 2011).

In this study, we performed an incubation experiment to compare changes in the availability of residual $\mathrm{Zn}$ from $\mathrm{Zn}$ natural chelates applied to two different soils according to moisture conditions.

\section{Materials and Methods}

The two original soil surface horizons used in this study were obtained from two different regions of Spain. Soil ${ }_{\text {acid }}$ was from Madrid $\left(40^{\circ} 17^{\prime} \mathrm{N}, 4^{\circ} 03^{\prime} \mathrm{W}\right)$ and Soil $1_{\text {calc }}$ was from Guadalajara $\left(40^{\circ} 39^{\prime}\right.$ N, $3^{\circ} 20^{\prime}$ W). Soil $l_{\text {acid }}$ was classified as a Typic Haploxeralf, and its main characteristics were as follows: sand, $840 \mathrm{~g} / \mathrm{kg}$; silt, $60 \mathrm{~g} / \mathrm{kg}$; clay, $100 \mathrm{~g} / \mathrm{kg}$; bulk density, $1.42 \mathrm{~g} \mathrm{~cm}^{-}$ 3; water-holding capacity ( $33 \mathrm{kPa}$ ), $6.60 \mathrm{~g} \mathrm{H}_{2} \mathrm{O} / 100$ $\mathrm{g}$ soil; $\mathrm{pH}, 6.13$; redox potential, $458 \mathrm{mV}$; electrical conductivity, $0.037 \mathrm{dS} / \mathrm{m}$; extractable $\mathrm{P}, 19.9 \mathrm{mg} / \mathrm{kg}$; oxidizable $\mathrm{OM}, 5.00 \mathrm{~g} / \mathrm{kg}$; total $\mathrm{N}, 1.00 \mathrm{~g} / \mathrm{kg}$; cation exchange capacity, $4.72 \mathrm{cmol} / \mathrm{kg} ; \mathrm{Fe}$ (active $\mathrm{Fe}_{2} \mathrm{O}_{3}$ ), $141 \mathrm{mg} / \mathrm{kg}$; total Zn, $9.97 \mathrm{mg} / \mathrm{kg}$. Soil calc $_{\text {was }}$ classified as a Typic Calcixerept, and its main characteristics were as follows: sand, $560 \mathrm{~g} / \mathrm{kg}$; silt, $260 \mathrm{~g} / \mathrm{kg}$; clay, $180 \mathrm{~g} / \mathrm{kg}$; bulk density, $1.06 \mathrm{~g} / \mathrm{cm}^{3}$; water-holding capacity $(33 \mathrm{kPa}), 20.5 \mathrm{~g} \mathrm{H}_{2} \mathrm{O} / 100 \mathrm{~g}$ soil; $\mathrm{pH}, 8.13$; redox potential, $380 \mathrm{mV}$; electrical conductivity, 0.178 $\mathrm{dS} / \mathrm{m}$; extractable $\mathrm{P}, 12.6 \mathrm{mg} / \mathrm{kg}$; oxidizable $\mathrm{OM}, 12.9$ $\mathrm{g} / \mathrm{kg}$; total N, $1.10 \mathrm{~g} / \mathrm{kg}$; cation exchange capacity, 23.5 $\mathrm{cmol}_{\mathrm{c}} / \mathrm{kg}$; Fe (active $\mathrm{Fe}_{2} \mathrm{O}_{3}$ ), $56 \mathrm{mg} / \mathrm{kg}$; total $\mathrm{Zn}, 44.25$ $\mathrm{mg} / \mathrm{kg}$ (Sparks et al., 1996).

The soils were obtained from an experiment performed during the previous year, which involved growing a flax crop in a greenhouse from March to June. Before growing the flax crop, these soils were treated with aqueous suspensions of three natural chelates: Zn-aminolignosulfonate (Zn-AML), Znpolyhydroxyphenylcarboxylate (Zn-PHP) and $\mathrm{Zn}$ ethylenediamine disuccinate (Zn-EDDS). These chelates were applied at different rates: 0,5 and 10 $\mathrm{mg} \mathrm{Zn/kg} \mathrm{(Alvarez} \mathrm{2010).} \mathrm{The} \mathrm{soil} \mathrm{from} \mathrm{the} \mathrm{pots}$ was homogenized, and the pots were then placed in a greenhouse for six months. Soil $(500 \mathrm{~g})$ from each pot was then placed in a polyethylene container with a capacity of $600 \mathrm{~mL}$. We used 84 containers in total: 
21 for each soil and moisture condition with two rates of three natural chelates and a control soil (Nil-Zn). Incubation was performed under two different moisture conditions: $60 \%$ field capacity and waterlogged conditions. Waterlogged conditions were determined when the water level was $1 \mathrm{~cm}$ above ground level; Soil ${ }_{\text {acid }}$ was at five times the field capacity, and Soil calc was at three times the field capacity. The containers were then sealed with Parafilm (PM-996) to prevent evaporation. The soil was mixed twice a week, and the moisture level was controlled by weight. We collected samples after 1, 15, 45 and 75 days. We then recalculated the amount of additional water needed to maintain these moisture conditions.

In the $60 \%$ field capacity samples, the available $\mathrm{Zn}$ concentration and short-term available Zn concentration were determined with diethylenetriaminepentaacetic acid - triethanolamine (DTPA-TEA) (Lindsay and Norwell, 1978) and low-molecular-weight organic acids (LMWOAs) (Feng et al.,2005), respectively. The water-soluble $\mathrm{Zn}$ was determined with $2.5 \mathrm{~g}$ of dry soil and $25 \mathrm{~mL}$ of deionized water; the solution was shaken for $30 \mathrm{~min}$ and then centrifuged (4000 rpm; 10 and 20 min for Soil ${ }_{\text {acid }}$ and Soil ${ }_{\text {calc }}$, respectively). The weight of dry soil used was corrected based on the previous moisture calculation. Soil $\mathrm{pH}$ and redox potential $\left(\mathrm{E}_{\mathrm{h}}\right)$ were measured using a Hamilton $\mathrm{pH}$ electrode (LP238285, $3 \mathrm{M} \mathrm{KCl}$ plus glycol electrolyte) and redox electrode (LP238145, Pt, $3 \mathrm{M} \mathrm{KCl} \mathrm{electrolyte).}$

In the waterlogged samples, a homogeneous $60 \mathrm{~g}$ sample of the supernatant was filtered using cellulose acetate membrane filters ("ALBET" AC 04547 $\mathrm{BL}$ ) to determine the $\mathrm{Zn}$ content in the soil solution (immediately available $\mathrm{Zn}$ ). We measured $\mathrm{pH}$ and $\mathrm{E}_{\mathrm{h}}$ in incubation containers. The available $\mathrm{Zn}$ concentration and short-term available $\mathrm{Zn}$ concentration were then determined using DTPA-TEA and LMWOAs, respectively. The weight of the dry soil used was corrected with the previous moisture calculation.

The $\mathrm{Zn}$ concentrations in the different extracts were determined by flame atomic absorption spectrometry with a Perkin-Elmer precisely AAS AAnalyst 700 (Perkin-Elmer, Waltham, MA, USA), which involved direct aspiration of the aqueous solution by an airacetylene flame. AA spectroscopy with a graphite furnace was used for low absorbance samples.

Statistical analyses were performed using Statgraphics Plus-5.1 software (Manugistic Inc., Rockville, MD, USA). Multiple comparisons of variables were performed using the LSD separations of means procedure. A probability level of $p \leq 0.05$ was selected to establish statistical significance.

\section{Results and Discussion}

\subsection{Incubation under $60 \%$ field capacity moisture conditions}

The mean $\mathrm{Zn}$ concentrations during soil incubation under $60 \%$ field capacity moisture conditions are shown in Table 1. In Soil $1_{\text {acid }}$, there were significant differences between the mean $\mathrm{Zn}$ concentrations over time $(p<0.05)$ (Figure 1).

In this soil, we observed significant differences $(p<$ 0.0001 ) between the mean available $\mathrm{Zn}$ concentrations in soils receiving the different treatments. The residual effect of the natural chelate $\mathrm{Zn}$-AML applied at a rate of $10 \mathrm{mg} \mathrm{Zn} / \mathrm{kg}$ produced the highest available and short-term available $\mathrm{Zn}$ concentrations. The available $\mathrm{Zn}$ concentrations obtained for all of the $\mathrm{Zn}$ treatments were higher than those reported as critical for plants grown in acidic soils by Lindsay and Norwell (1978); the observed values were between 6.10 and 13.87 times greater than the critical level (Zn-PHP applied at a rate of $5 \mathrm{mg} \mathrm{Zn/kg}$ and $\mathrm{Zn}$-AML applied at a rate of $10 \mathrm{mg} \mathrm{Zn} / \mathrm{kg}$, respectively). This finding was in agreement with the short-term available $\mathrm{Zn}$ concentration values, which ranged between 2.34 and 4.87 times the $\mathrm{Zn}$ concentration with Nil-Zn treatment (Zn-PHP applied at a rate of $5 \mathrm{mg} \mathrm{Zn/kg}$ and $\mathrm{Zn}-\mathrm{AML}$ applied at a rate of $10 \mathrm{mg} \mathrm{Zn/kg}$, respectively). 
Table 1. The mean $\mathrm{Zn}$ concentrations under $60 \%$ field capacity moisture conditions in both soil types were influenced by the incubation period (days) and the source of Zn fertilizer ${ }^{(a)}$

\begin{tabular}{|c|c|c|c|c|c|c|}
\hline \multirow[b]{2}{*}{$\begin{array}{l}\text { Source of } \\
\text { variation }\end{array}$} & \multicolumn{3}{|c|}{ Soil $_{\text {acid }}$} & \multicolumn{3}{|c|}{ Soil $_{\text {calc }}$} \\
\hline & $\begin{array}{l}\text { Available } \mathrm{Zn} \\
\left(\mathrm{mg} \mathrm{kg}^{-1}\right)^{(\mathrm{b})}\end{array}$ & $\begin{array}{l}\text { Short-term } \\
\text { available } \mathrm{Zn} \\
\left(\mathrm{mg} \mathrm{kg}^{-1}\right)^{(\mathrm{c})}\end{array}$ & $\begin{array}{l}\text { Water-soluble } \mathrm{Zn} \\
\qquad\left(\mu \mathrm{L} \mathrm{L}^{-1}\right)^{(\mathrm{d})}\end{array}$ & $\begin{array}{c}\text { Available Zn } \\
\left(\mathrm{mg} \mathrm{kg}^{-1}\right)\end{array}$ & $\begin{array}{l}\text { Short-term } \\
\text { available } \mathrm{Zn} \\
\left(\mu \mathrm{g} \mathrm{kg}^{-1}\right)\end{array}$ & $\begin{array}{c}\text { Water-soluble } \\
\mathrm{Zn}\left(\mu \mathrm{g} \mathrm{L}^{-1}\right)\end{array}$ \\
\hline \multicolumn{7}{|c|}{ Incubation period (days) } \\
\hline 1 & $5.41 \mathrm{~b}$ & $4.7 \mathrm{c}$ & $57.82 \mathrm{c}$ & $2.52 \mathrm{~b}$ & $109.1 \mathrm{~d}$ & $18.29 \mathrm{c}$ \\
\hline 15 & $5.31 \mathrm{ab}$ & $4.53 \mathrm{bc}$ & $55.42 \mathrm{bc}$ & $2.13 \mathrm{a}$ & $96.68 \mathrm{c}$ & $15.43 \mathrm{~b}$ \\
\hline 45 & $5.3 \mathrm{ab}$ & $4.32 \mathrm{ab}$ & $52.86 \mathrm{~b}$ & $2.06 \mathrm{a}$ & $72.74 \mathrm{~b}$ & 14.14 a \\
\hline 75 & $5.22 \mathrm{a}$ & $4.22 \mathrm{a}$ & $49.43 \mathrm{a}$ & $1.99 \mathrm{a}$ & $60.42 \mathrm{a}$ & $13.71 \mathrm{a}$ \\
\hline \multicolumn{7}{|l|}{ Treatment } \\
\hline Nil-Zn & $1.81 \mathrm{a}$ & $1.38 \mathrm{a}$ & $31.0 \mathrm{a}$ & $0.81 \mathrm{a}$ & $44.0 \mathrm{a}$ & $9.8 \mathrm{a}$ \\
\hline Zn-AML-5 & $4.08 \mathrm{~b}$ & $3.94 \mathrm{c}$ & $50.0 \mathrm{~b}$ & $1.89 \mathrm{c}$ & $55.5 \mathrm{~b}$ & $13.5 \mathrm{~b}$ \\
\hline Zn-AML-10 & $8.32 \mathrm{~d}$ & $6.72 \mathrm{e}$ & $62.3 \mathrm{~cd}$ & $3.33 \mathrm{f}$ & $81.5 \mathrm{e}$ & $15.5 \mathrm{c}$ \\
\hline Zn-PHP-5 & $3.66 \mathrm{~b}$ & $3.23 \mathrm{~b}$ & $59.0 \mathrm{c}$ & $1.64 \mathrm{~b}$ & $57.3 \mathrm{c}$ & $13.3 \mathrm{~b}$ \\
\hline Zn-PHP-10 & $7.63 \mathrm{c}$ & $6.08 \mathrm{~d}$ & $63.5 \mathrm{~d}$ & $2.45 \mathrm{~d}$ & $68.2 \mathrm{~d}$ & $19.8 \mathrm{e}$ \\
\hline Zn-EDDS-5 & $4.33 \mathrm{~b}$ & $3.84 \mathrm{c}$ & $52.3 \mathrm{~b}$ & $2.00 \mathrm{c}$ & $134.8 \mathrm{f}$ & $17.5 \mathrm{~d}$ \\
\hline $\begin{array}{l}\text { Zn-EDDS- } \\
10\end{array}$ & $7.34 \mathrm{c}$ & $5.91 \mathrm{~d}$ & $59.2 \mathrm{c}$ & $3.11 \mathrm{e}$ & $152.0 \mathrm{~g}$ & $18.5 \mathrm{de}$ \\
\hline
\end{tabular}

(a) Values were compared using the LSD multiple range test at the 0.05 level of probability. Homogeneous groups are denoted with the same letter. (b) Estimated by the DTPA-TEA method. ${ }^{(c)}$ Estimated by the low-molecular-weight organic acids (LMWOAs) method. ${ }^{\text {(d) }}$ A mixture containing $2.5 \mathrm{~g}$ of dry soil and $25 \mathrm{~mL}$ of deionized water was shaken for $30 \mathrm{~min}$ and centrifuged.

The Zn-EDDS treatments produced values similar to $\mathrm{Zn}$-AML applied at a rate of $5 \mathrm{mg} \mathrm{Zn/kg}$ and to $\mathrm{Zn}-\mathrm{PHP}$ applied at $10 \mathrm{mg} \mathrm{Zn/kg}$. When this chelate was applied to the previous crop at the higher rate $(10 \mathrm{mg} \mathrm{Zn} / \mathrm{kg})$, it produced an excessive concentration of available $\mathrm{Zn}$ and caused phytotoxicity in flax plants grown in the acidic soil of the previous crop. The residual effect of $\mathrm{Zn}$-PHP applied at a rate of $10 \mathrm{mg} \mathrm{Zn/kg}$ produced the highest water-soluble $\mathrm{Zn}$ concentration. These $\mathrm{Zn}$ concentrations were between 1.61 and 2.05 times those associated with Nil-Zn treatment (Zn-AML applied at a rate of $5 \mathrm{mg} \mathrm{Zn/kg}$ and $\mathrm{Zn}-\mathrm{PHP}$ applied at $10 \mathrm{mg} \mathrm{Zn/kg}$, respectively). In Soil ${ }_{\text {calc }}$, there were significant differences between the mean available $\mathrm{Zn}$ concentrations over time $(p<0.05)$ (Figure 1). The mean short-term available $\mathrm{Zn}$ concentrations also differed over time $(p<0.0001)$, as did the water-soluble $\mathrm{Zn}$ concentrations $(p<0.001)$. In this soil, we observed significant differences between the mean available $\mathrm{Zn}$ concentrations in soil $(p<$ $0.0001)$ with the application of different treatments. The residual effect of the natural chelate $\mathrm{Zn}-\mathrm{AML}$, applied at the rate of $10 \mathrm{mg} \mathrm{Zn/kg}$, produced the highest available concentration. The available $\mathrm{Zn}$ concentrations obtained for all of the $\mathrm{Zn}$ treatments were higher than the critical level for most plants grown in calcareous soils, with values reaching between 1.89 and 3.33 times the critical level (Zn-AML applied at a rate of $5 \mathrm{mg} \mathrm{Zn/kg}$ and $\mathrm{Zn}$-AML applied at a rate of 10 $\mathrm{mg} \mathrm{Zn/kg}$, respectively). On the other hand, Zn-EDDS applied at both rates produced the highest short-term available $\mathrm{Zn}$ concentrations. 

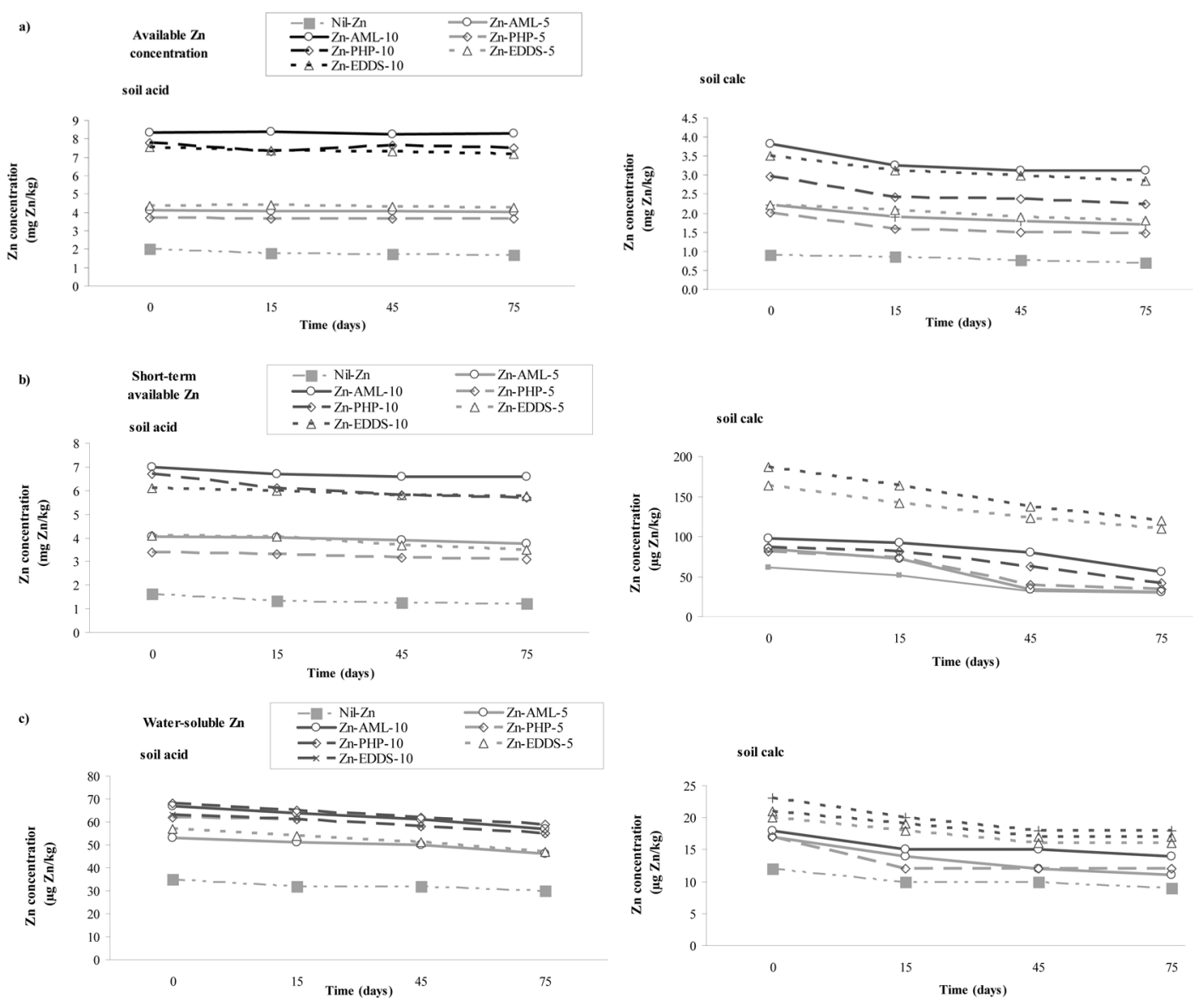

Figure 1. Time course of changes in the available (a), short-term available (b) and water-soluble (c) $\mathrm{Zn}$ concentrations in both soil types showing the residual effects of each treatment under $60 \%$ field capacity conditions.

These $\mathrm{Zn}$ concentrations were between 1.26 and 3.45 times greater than the $\mathrm{Zn}$ concentration with Nil-Zn treatment ( $\mathrm{Zn}-\mathrm{AML}$ applied at a rate of $5 \mathrm{mg} \mathrm{Zn} /$ $\mathrm{kg}$ and $\mathrm{Zn}$-EDDS applied at a rate of $10 \mathrm{mg} \mathrm{Zn/kg}$, respectively). The residual effect of $\mathrm{Zn}$-PHP applied at a rate of $10 \mathrm{mg} \mathrm{Zn} / \mathrm{kg}$ produced the highest water-soluble $\mathrm{Zn}$ concentration. The application of Zn-EDDS at both rates also produced high water-soluble $\mathrm{Zn}$ concentrations. Aminopolycarboxylate chelating agents (e.g., EDDS) generally form complexes with high stability constants $\left(\log \mathrm{K}_{\mathrm{Zn} \text {-EDDS }}=13.4\right)$, which causes high short-term availability of the micronutrient over time (Martell et al., 2001; Tandy et al., 2004; Nörtemann, 2005; Nowack et al., 2006).

In Soil ${ }_{\text {acid }}$, the mean $\mathrm{Zn}$ concentrations were 2.44 (available $\mathrm{Zn}$ ), 52.43 (short-term available $\mathrm{Zn}$ ) and 3.50 (water-soluble $\mathrm{Zn}$ ) times greater than those in Soil calc $^{\text {. }}$. 
The characteristics of Soil cale $_{\text {, }}$ which include its alkaline $\mathrm{pH}$, high $\mathrm{CaCO}_{3}$ concentration and high clay content, caused $\mathrm{Zn}$ immobilization due to the formation of hydroxides and carbonates in addition to the adsorption of $\mathrm{Zn}$ to the clay.

The differences between the $\mathrm{Zn}$ concentrations extracted by the different methods were due to the different extraction capacities of the reagents. The available $\mathrm{Zn}$ concentration method (DTPA-TEA) extracts water-soluble metal that is exchangeable, sorbed and organically associated, some of which is occluded in oxides and secondary clay minerals (Viets, 1962; Ure, 1995). However, the short-term available Zn (LMWOAs) method extracts the amount of metal responsible for short-term availability (Cieśliński et al., 1998) and for most of the metal available to the plant. Water-soluble $\mathrm{Zn}$ is the most labile micronutrient fraction.

The most significant correlation between the different $\mathrm{Zn}$ concentrations obtained from the two soils revealed a significant positive correlation between short-term available $\mathrm{Zn}$ and water-soluble $\mathrm{Zn}(r=0.96 ; p<0.0001)$. We obtained the following regression equation:

$\mathrm{Zn}$ - $($ water-soluble $)=16.7+7.92 \mathrm{Zn}$-(short-term available) $\left(\mathrm{R}^{2}=91.81 \%\right)$

Under $60 \%$ field capacity conditions, significant differences were noted between the experimental times for redox potential values $\left(p<0.001\right.$ in Soil ${ }_{\text {acid }}, p<$ 0.0001 in Soil calc $_{\text {). In Soil }}$ acid, we observed an increase in this parameter, with mean Eh values ranging between $488 \mathrm{mV}$ at $1 \mathrm{~d}$ and $598 \mathrm{mV}$ at $75 \mathrm{~d}$. On the other hand, in Soil $_{\text {calc }}$, the mean Eh values ranged between 673 $\mathrm{mV}$ at $1 \mathrm{~d}$ and $477 \mathrm{mV}$ at $75 \mathrm{~d}$. Under these moisture conditions, we also observed significant differences in soil $\mathrm{pH}$ between experimental times $\left(p<0.05\right.$ in Soil $_{\text {acid, }}$ $p<0.001$ in Soil $_{\text {calc }}$ ). In Soil ${ }_{\text {acid }}$, the mean soil $\mathrm{pH}$ values ranged between 6.33 at $1 \mathrm{~d}$ and 6.07 at $75 \mathrm{~d}$. In Soil calc, the mean $\mathrm{pH}$ values ranged between 7.84 at $1 \mathrm{~d}$ and 8.30 at $75 \mathrm{~d}$. The parameter $\mathrm{pH}+$ pe $\left[\mathrm{pe}=\mathrm{E}_{\mathrm{h}}(\mathrm{mV}) / 59.2\right]$, where pe is the negative logarithm of free electron activity, provides a convenient single-term expression for defining the redox status of soil systems. Significant differences in this parameter were noted under $60 \%$ field capacity conditions $(p<0.001$ and $p<0.0001$ for Soil acid and Soil ${ }_{\text {calc }}$, respectively). In Soil acid $\mathrm{pH}+$ pe increased with time, whereas in Soil calc, it decreased from 1 to $75 \mathrm{~d}$. According to Sparks (1996), the $\mathrm{pH}$ and pe values that were obtained for the two soils under $60 \%$ field capacity conditions would correspond to "oxic" or "normal" soils $(\mathrm{pH}+\mathrm{pe}>14)$.

\subsection{Incubation under waterlogged moisture conditions}

The mean $\mathrm{Zn}$ concentrations during soil incubation under waterlogged moisture conditions are shown in Table 2. In Soil ${ }_{\text {acid }}$, there were significant differences between the mean $\mathrm{Zn}$ concentrations over time ( $p<$ 0.05 for available and short-term available $\mathrm{Zn} ; p<$ 0.0001 for immediately available $\mathrm{Zn}$ ) (Figure 2).

In Soil $_{\text {acid, }}$ we observed significant differences between the mean $\mathrm{Zn}$ concentrations $(p<0.0001)$ with the different treatments. The residual effect of the natural chelate $\mathrm{Zn}$-AML when applied at the highest rate $(10 \mathrm{mg} \mathrm{Zn} / \mathrm{kg})$ produced the greatest available, short-term available and immediately available $\mathrm{Zn}$ concentrations. The available $\mathrm{Zn}$ concentrations obtained for all of the $\mathrm{Zn}$ treatments were higher than those reported as critical for plants grown in acidic soils. These concentrations reached values that were between 3.73 and 11.05 times greater than the critical concentration (Zn-EDDS applied at a rate of $5 \mathrm{mg} \mathrm{Zn/kg}$ and $\mathrm{Zn}$-AML applied at a rate of $10 \mathrm{mg} \mathrm{Zn/kg}$, respectively). Short-term available and immediately available $\mathrm{Zn}$ concentrations were also high under treatments involving residual $\mathrm{Zn}$. The short-term available $\mathrm{Zn}$ concentrations were between 2.12 and 5.44 times greater than the Nil$\mathrm{Zn}$ concentration, and the immediately available $\mathrm{Zn}$ concentrations were between 2.58 and 6.00 times greater than the Nil-Zn concentration (Zn-PHP applied at s rate of $5 \mathrm{mg} \mathrm{Zn/kg}$ and $\mathrm{Zn}$-AML applied at a rate of $10 \mathrm{mg} \mathrm{Zn/kg}$ in both cases). 
Table 2. The mean $\mathrm{Zn}$ concentrations under waterlogged conditions in both soil types, were influenced by the incubation period (days) and the source of $\mathrm{Zn}$ fertilizer ${ }^{(\mathrm{a})}$

\begin{tabular}{|c|c|c|c|c|c|c|}
\hline \multirow[b]{2}{*}{$\begin{array}{l}\text { Source of } \\
\text { variation }\end{array}$} & \multicolumn{3}{|c|}{ Soil $_{\text {acid }}$} & \multicolumn{3}{|c|}{ Soil $_{\text {calc }}$} \\
\hline & $\begin{array}{c}\text { Available Zn } \\
\left(\mathrm{mg} \mathrm{kg}^{-1}\right)^{(\mathrm{b})}\end{array}$ & $\begin{array}{l}\text { Short-term } \\
\text { available } \mathrm{Zn} \\
\left(\mathrm{mg} \mathrm{kg}^{-1}\right)^{(\mathrm{c})}\end{array}$ & $\begin{array}{l}\text { Immediately } \\
\text { available } \mathrm{Zn} \\
\left(\mathrm{mg} \mathrm{L}^{-1}\right)^{(\mathrm{d})}\end{array}$ & $\begin{array}{l}\text { Available } \mathrm{Zn} \\
\left(\mathrm{mg} \mathrm{kg}^{-1}\right)\end{array}$ & $\begin{array}{l}\text { Short-term } \\
\text { available } \mathrm{Zn} \\
\left(\mu \mathrm{g} \mathrm{kg}^{-1}\right)\end{array}$ & $\begin{array}{c}\text { Immediately } \\
\text { available } \mathrm{Zn} \\
\left(\mu \mathrm{g} \mathrm{L}^{-1}\right)\end{array}$ \\
\hline \multicolumn{7}{|c|}{ Incubation period (days) } \\
\hline 1 & $3.95 \mathrm{~b}$ & $3.79 \mathrm{c}$ & $2.00 \mathrm{~d}$ & $1.96 \mathrm{c}$ & $107 \mathrm{~d}$ & $29.7 \mathrm{~d}$ \\
\hline 15 & $3.74 \mathrm{ab}$ & $3.61 \mathrm{bc}$ & $1.77 \mathrm{c}$ & $1.86 \mathrm{bc}$ & $91.7 \mathrm{c}$ & $26.7 \mathrm{c}$ \\
\hline 45 & $3.59 \mathrm{a}$ & $3.54 \mathrm{ab}$ & $1.40 \mathrm{~b}$ & $1.76 \mathrm{ab}$ & $58.7 \mathrm{~b}$ & $20.7 \mathrm{~b}$ \\
\hline 75 & $3.47 \mathrm{a}$ & $3.38 \mathrm{a}$ & $1.16 \mathrm{a}$ & $1.72 \mathrm{a}$ & $42.6 \mathrm{a}$ & $15.3 \mathrm{a}$ \\
\hline \multicolumn{7}{|l|}{ Treatment } \\
\hline Nil-Zn & $1.36 \mathrm{a}$ & $1.09 \mathrm{a}$ & $0.43 \mathrm{a}$ & $0.64 \mathrm{a}$ & $25.8 \mathrm{a}$ & $17.5 \mathrm{a}$ \\
\hline Zn-AML-5 & $3.21 \mathrm{c}$ & $2.96 \mathrm{c}$ & $1.37 \mathrm{c}$ & $1.45 \mathrm{~b}$ & $46.8 \mathrm{~b}$ & $19.8 \mathrm{~b}$ \\
\hline Zn-AML-10 & $6.63 \mathrm{f}$ & $5.93 \mathrm{e}$ & $2.58 \mathrm{e}$ & $2.73 \mathrm{e}$ & $67.5 \mathrm{c}$ & $28.8 \mathrm{~d}$ \\
\hline Zn-PHP-5 & $2.30 \mathrm{~b}$ & $2.31 \mathrm{~b}$ & $1.11 \mathrm{~b}$ & $1.45 \mathrm{~b}$ & $44.5 \mathrm{~b}$ & $20.8 \mathrm{~b}$ \\
\hline Zn-PHP-10 & $4.84 \mathrm{~d}$ & $4.62 \mathrm{~d}$ & $1.99 \mathrm{~d}$ & $2.08 \mathrm{~d}$ & $60.3 \mathrm{c}$ & $21.3 \mathrm{~b}$ \\
\hline Zn-EDDS-5 & $2.24 \mathrm{~b}$ & $3.25 \mathrm{c}$ & $1.50 \mathrm{c}$ & $1.60 \mathrm{c}$ & $130 \mathrm{~d}$ & $25.5 \mathrm{c}$ \\
\hline Zn-EDDS-10 & $5.26 \mathrm{e}$ & $4.90 \mathrm{~d}$ & $2.12 \mathrm{~d}$ & $2.85 \mathrm{f}$ & $150 \mathrm{e}$ & $28.3 \mathrm{~d}$ \\
\hline
\end{tabular}

(a) Values were compared using LSD multiple range test at the 0.05 level of probability. Homogeneous groups are denoted with the same letter. (b) Estimated by the DTPA-TEA method. ${ }^{(c)}$ Estimated by the low-molecular-weight organic acids (LMWOAs) method. (d) $\mathrm{Zn}$ in the soil solution.

In Soil calc $_{\text {, }}$ there were significant differences between the mean $\mathrm{Zn}$ concentrations over time ( $p<0.05$, available $\mathrm{Zn}$ concentration; $p<0.0001$, short-term and immediately available $\mathrm{Zn}$ concentrations).

In Soil ${ }_{\text {calc }}$, there were significant differences between the $\mathrm{Zn}$ concentrations associated with the different treatments $(p<0.0001)$. The residual effect of Zn-EDDS applied at the highest rate $(10 \mathrm{mg} \mathrm{Zn/kg})$ produced the highest available, short-term available and immediately available $\mathrm{Zn}$ concentrations. The residual effect of $\mathrm{Zn}$ EDDS applied at a rate of $5 \mathrm{mg} \mathrm{Zn/kg}$ also produced high $\mathrm{Zn}$ concentrations that, in some cases, were even greater than those obtained with other natural chelates, such as $\mathrm{Zn}-\mathrm{PHP}$ and Zn-AML applied at a rate of $10 \mathrm{mg} \mathrm{Zn/kg}$. This characteristic of Zn-EDDS could be explained by the high stability of the complex and, more specifically, by the relatively strong complexing ability of $\mathrm{Zn}$, which allows the maintenance of high $\mathrm{Zn}$ concentrations even under waterlogged conditions. $\mathrm{Zn}$ concentrations, especially the concentrations of available and shortterm available $\mathrm{Zn}$, showed major decreases when $\mathrm{Zn}$ EDDS was applied at both doses (Figure 2). This result was in agreement with those reported by Tandy et al. (2006), who observed decreases in metal concentrations over time that were clearly coupled to the degradation of EDDS. Tandy et al. showed that the application of EDDS under temporarily anoxic conditions ( 24 hours) in three different saturated soils resulted in initially high soluble $\mathrm{Zn}$ concentrations that gradually decreased to only trace levels by day 21; after day 35 , the concentration of the Zn-EDDS complex was extremely low. 

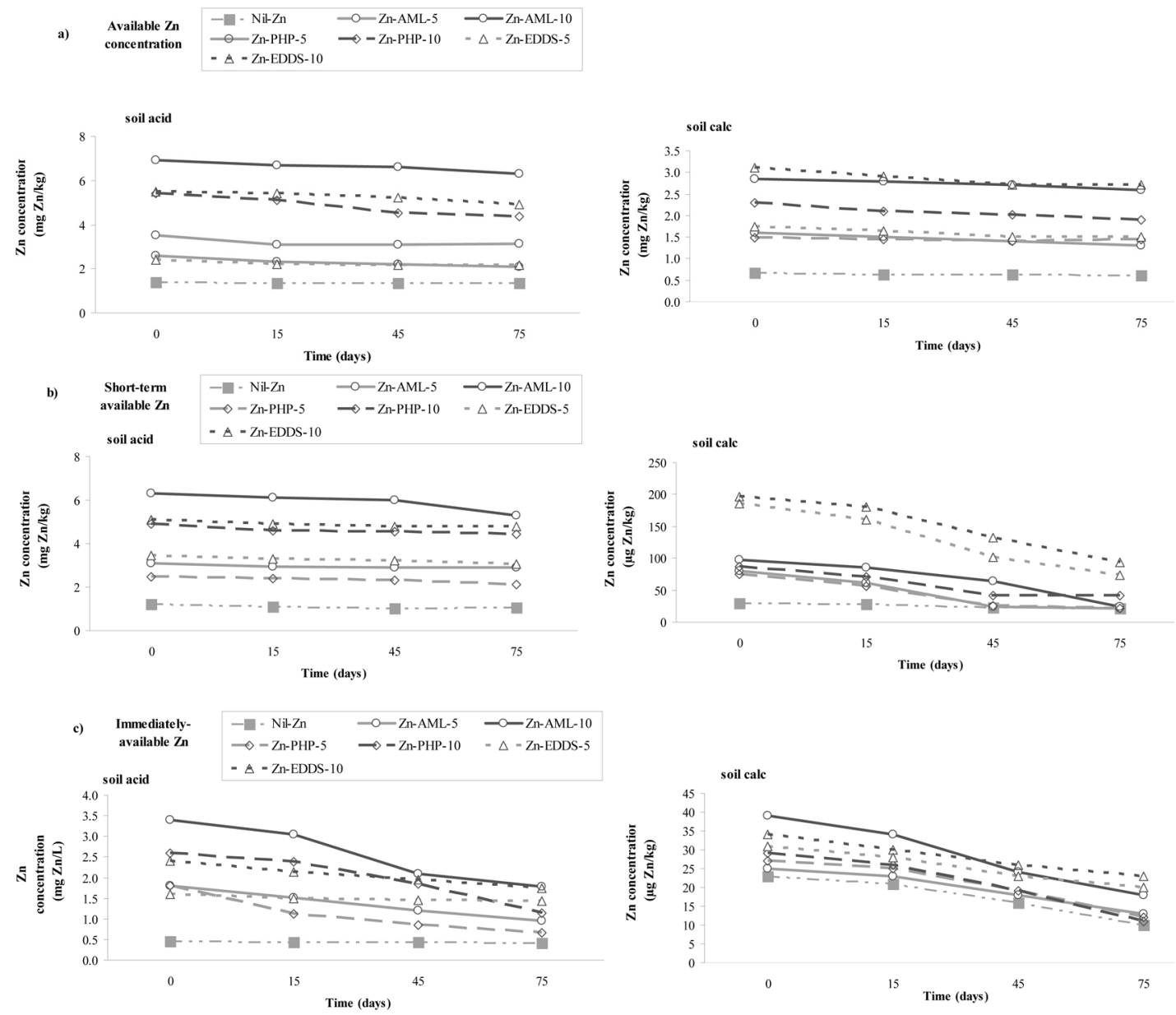

Figure 2. Time course of changes in available (a), short-term available (b) and immediately available (c) $\mathrm{Zn}$ concentrations in both soil types showing the residual effects of each treatment under waterlogged conditions.

In Soil acid, the available, short-term and immediately available mean $\mathrm{Zn}$ concentrations were 1.96, 21.33 and 82.8 times higher, respectively, than those in Soil calc $^{*}$ The alkaline $\mathrm{pH}$ most likely caused the $\mathrm{Zn}$ to be less soluble.

Immediately available $\mathrm{Zn}$, or the $\mathrm{Zn}$ concentration in the soil solution, is the water-soluble form of $\mathrm{Zn}$ (ion, small molecule or dissolved gas) that can rapidly move through protein transporter channels in plant and microbial cell membranes (Hedley, 2008). The correlation between the immediately available $\mathrm{Zn}$ and short-term available $\mathrm{Zn}$ concentrations in the two soils showed a significant negative correlation $(r=-0.79$; $p<0.001)$. The following regression equation was obtained: 
Zn-(immediately available) $=20.19-4.29$ Zn-(shortterm available) $\left(\mathrm{R}^{2}=63.13 \%\right)$

In both soils, the redox potential values measured under waterlogged conditions significantly decreased $(p<$ 0.0001 and $p<0.05$ for Soil ${ }_{\text {acid }}$ and Soil $l_{\text {calc }}$, respectively) between 1 and $75 \mathrm{~d}$. In Soil ${ }_{\text {acid }}$, these values ranged between 379 and $327 \mathrm{mV}$ at 1 and $75 \mathrm{~d}$, respectively. In Soil calc $_{\text {, }}$ the mean values at 1 and $75 \mathrm{~d}$ were 266 and 245 $\mathrm{mV}$, respectively. The $\mathrm{pH}$ values did not significantly differ between 1 and 75d, with mean values ranging between 5.10 and 5.29 in Soil $_{\text {acid }}$ and between 7.19 and 7.27 in Soil $_{\text {calc }}$. Under waterlogged conditions, the $\mathrm{pH}+$ pe parameter did not show any significant differences with time. According to Sparks (1996), the $\mathrm{pH}$ and pe values obtained for the two soils would correspond to "wet" or "seasonally saturated" soils.

We compared the available $\mathrm{Zn}$ concentrations in soil under different moisture conditions. The available $\mathrm{Zn}$ concentration under moisture conditions of $60 \%$ field capacity was compared with the sum of the available $\mathrm{Zn}$ and immediately available $\mathrm{Zn}$ concentrations under waterlogged conditions (considering bulk density). The percentages of recovered $\mathrm{Zn}$ under $60 \%$ field capacity conditions with respect to waterlogged conditions were $8.81 \%$ for Soil ${ }_{\text {acid }}$ and $19.51 \%$ for Soil calc We also compared the short-term available $\mathrm{Zn}$ under $60 \%$ field capacity conditions and the sum of the shortterm available $\mathrm{Zn}$ and the immediately available $\mathrm{Zn}$ concentrations under waterlogged conditions. The percentage of recovered $\mathrm{Zn}$ under waterlogged conditions with respect to $60 \%$ field capacity conditions reached $11.54 \%$ for Soil ${ }_{\text {acid }}$ and $11.87 \%$ for Soil calc $^{\text {. }}$ These results could be explained by the fact that under waterlogged conditions, the redox potential decreases and Fe (III) and Mn (III, IV) oxides are dissolved because of the reduction of $\mathrm{Fe}$ and $\mathrm{Mn}$ (Millaleo et $a l ., 2010)$. This effect may have been caused by the $\mathrm{Zn}$ redistribution and the increase in the $\mathrm{Zn}$ concentration in the most labile fractions (in the form of immediately available and short-term available $\mathrm{Zn}$ ).

\section{Conclusions}

Moisture conditions influence the concentrations of available, short-term available, immediately available and water-soluble $\mathrm{Zn}$ in soils. These concentrations also depend on the length of the experiment, the soil type and the $\mathrm{Zn}$-chelate used. Over time, changes were observed in the concentrations of residual $\mathrm{Zn}$ from natural chelates in both soils and under both moisture conditions. Available, short-term available and immediately available $\mathrm{Zn}$ concentrations decreased from 1 to $75 \mathrm{~d}$. Under waterlogged conditions, shortterm available $\mathrm{Zn}$ and immediately available $\mathrm{Zn}$ concentrations were increased compared with their concentrations under $60 \%$ field capacity conditions. In general, the residual effects of Zn-AML applied at a rate of $10 \mathrm{mg} \mathrm{Zn/kg}$ in Soil acid and Zn-EDDS applied in Soil calc produced the highest $\mathrm{Zn}$ concentrations under both moisture conditions. The $\mathrm{Zn}$ concentrations in soils that received $\mathrm{Zn}$ treatments were sufficient to meet the needs of most crops, particularly in the acidic soil, where $\mathrm{Zn}$ concentrations reached their highest values.

\section{Acknowledgements}

Financial support for this study was provided by Spain DGI (MEC; project: AGL2009-12741).

\section{References}

Almendros, P., Gonzalez, D., Alvarez, J.M. 2011. Residual effect of natural and synthetic zinc chelates on zinc in a soil solution of a waterlogged acidic soil. Evolution of the $\mathrm{pH}$ and redox potential. EGU General Assembly, Viena.

Alvarez, J.M. 2010. Influence of soil type and natural $\mathrm{Zn}$ chelates on flax response, tensile properties and soil $\mathrm{Zn}$ availability. Plant and Soil. 328, 217-233. 
Alvarez, J.M., Rico, M.I. 2003. Effect of zinc complexes on the distribution of zinc in calcareous soil and zinc uptake by maize. Journal of Agricultural and Food Chemistry. 51, 5760-5767.

Armour, J.D., Ritchie, G.S.P., Robson, A.D. 1989. Changes with time in the availability of soil applied zinc to navy beans and in the chemical extraction of zinc from soils. Australian Journal of Soil Research. 27, 699-710.

Barrow, N.J. 1986. Test a mechanistic model. II. The effects of time and temperature on the reaction of zinc with a soil. Soil Science. 37, 277-286.

Cieśliński, G., Van Rees, K.C.J., Szmigielska, A.M., Krishnamurti, G.S.R., Huang, P.M. 1998. Lowmolecular-weight organic acids in rhizosphere soils of durum wheat and their effect on cadmium bioaccumulation Plant and Soil. 203, 109-117.

Feng, M.H., Shan, X.Q., Zhang, S.Z., Wen, B. 2005. Comparison of a rhizosphere-based method with other one-step extraction methods for assessing the bioavailability of soil metals to wheat. Chemosphere. 59, 939-949.

Hedley, M.J. 2008. Techniques for assessing nutrient bioavailability in soils: current and future issues. Developments in Soil Science. 32, 283-327.

Liang, J., Steward, J.W.B., Karamanos, R.E. 1990. Distribution of zinc fractions in preirie soils. Canadian Journal of Soil Science. 70, 335-342.

Lindsay, W.L., Norvell, W.A. 1978. Development of a DTPA soil test for zinc, iron, manganese, and copper. Soil Science Society of America Journal. 42, 421-428.

Lopez-Valdivia, L.M., Fernández, M.D., Obrador, A., Alvarez, J.M. 2002. Zinc transformations in acidic soil and zinc efficiency on maize by adding six organic zinc complexes. Journal of Agricultural and Food Chemistry. 50, 1455-1460.
Ma, Y.B., Uren, N.C. 2006. Effect of aging on the availability of zinc added to a calcareous clay soil. Nutrient Cycling in Agroecosystems. 76, 11-18.

Martell, A.E., Smith, R.M., Motekaitis, R.J. 2001. NIST critically selected stability constants of metal complexes database.

Martinez, C.E., McBride, M.B. 2000. Aging of coprecipitated $\mathrm{Cu}$ in alumina: changes in structural location, chemical form, and solubility. Geochimica et Cosmochimica Acta. 64, 1729-1736.

McBride, M.B. 1994. 'Environmental chemistry of soil.' (Oxford University Press: NY)

Millaleo, R., Reyes-Diaz, M., Ivanov, A.G., Mora, M.L., Alberdi, M. 2010. Manganese as essential and toxic elements for plants: transport, accumulation and resistance mechanisms. Journal of soil science and plant nutrition. 10, 470-481.

Nörtemann, B. 2005. Biodegradation of chelating agents: EDTA, DTPA, PDTA, NTA, and EDDS. In: B. Nowack, J.M. VanBriesen (eds). Biogeochemistry of chelating agents. ACS Symposium Series 910. Journal of the American Chemistry Society: Washington DC, USA. pp: 150-170.

Nowack, B., Shulin, R., Robinson, B.H. 2006. Critical assessment of chelant enhanced metal phytoextraction. Environmental Science and Technology. 40, 5225-5232.

Obrador, A., Alvarez, J.M., Fernandez, M.D., LopezValdivia, L.M. 2002. Changes with time of zinc forms in an acid, a neutral, and a calcareous soil amended with three organic zinc complexes. Australian Journal of Soil Research. 40, 137-148.

Payne, G.G., Martens, D.C., Winarko, C., Perera, N.F. 1988. Form and availability of copper and zinc following long-term copper sulfate and zinc sulfate applications Journal of Environmental Quality. 17, 707-711. 
Shuman, L.M. 1991. Chemical forms of micronutrients in soils. In: J.J. Mortvedt, F.R. Cox, L.M. Shuman, R.M. Welch (eds). Micronutrients in agriculture. Soil Science Society of America: Madison, WI. pp. 113-144.

Sparks, D.L., Bartels, J., Bigham, J. 1996. Methods of soil analysis. Part 3, chemical methods. Soil Science Society of America: Madison, WI.

Tandy, S., Bossart, K., Mueller, R., Ritschel, J., Hauser, L., Schulin, R., Nowack, B. 2004. Extraction of heavy metals from soils using biodegradable chelating agents. Environmental Science and Technology. 38, 937-944.

Tandy, S., Ammann, A., Schulin, R., Nowack, B. 2006. Biodegradation and speciation of residual SS-ethylenediaminedisuccinic acid (EDDS) in soil solution left after soil washing. Journal of Environment and Pollution. 142, 191-199.
Tiller, K.G., Honeysett, J.L., De Vries, M.P.C. 1972. Soil zinc and its uptake by plants. I. Isotopic exchange equilibria and the application of tracer techniques. Australian Journal of Soil Research. $10,151-164$

Ure, A.M. 1995. Methods of analysis for heavy metals in soils. In B.J. Alloway (ed). Heavy metals in soils. Blackie Academic and Professional: Glasgow, UK. pp. 58-102.

Viets, F.G. 1962. Micronutrient availability, chemistry and availability of micronutrients in soils. Journal of Agricultural and Food Chemistry. 10, 174-178.

Violante, A., Cozzolino, V., Perelomov, L., Caporale, A.G., Pigna, M. 2010. Mobility and bioavailability of heavy metals and metalloids in soil environments. Journal of Soil Science and Plant Nutrition. 3, 268-292. 